The environmental and human health impacts of dairy intensification:

\title{
A CASE STUDY - CANTERBURY
}

Mike Joy, Senior Researcher at the Institute for Governance and Policy Studies, Victoria University of Wellington, argues that New Zealand is in the midst of a freshwater crisis brought on by dairy intensification. Nowhere is that better illustrated than in Canterbury, whose water quality is increasingly threatened by nitrate contamination.

NEW ZEALAND HAS a freshwater crisis. The most comprehensive indicator of this is the rapid decline in aquatic biodiversity. Three-quarters of native fish are listed as threatened or at risk of extinction. This is up from one-fifth in the 1990s. Our proportion of threatened species ranks with the worst in the world. Terrestrial biodiversity is also in crisis. We have the highest proportion of threatened species globally, with around one-third of all species listed as threatened or at risk of extinction. A further third are listed as 'data deficient', probably because they are hard to find.

No native freshwater fish species has any real protection under law. Rather than being covered by the Wildlife Act 1953, they are instead covered by the Freshwater Fisheries Act 1983, which affords them virtually no protection, with the sole exception of the comprehensive protection granted one species. That species is the grayling, which went extinct in the 1930s. Even more gallingly, the Fisheries Act gives strong protection to introduced fishery species of salmonids, including trout.

Probably the best way to illustrate the circumstances that led to this freshwater crisis is with a regional case study. Canterbury is ideal, as the changes in this region have been recent and extensive. Beginning in the 1990s, Canterbury underwent a rapid land use transformation, from sheep and mixed cropping to irrigated dairy (Figure 1). The conversion was driven by a combination of local, national 
and international market factors, and enabled by a lack of central or local government regulation, and taxpayer subsidised irrigation schemes.

The transformation required a supply of irrigation water in a region with low rainfall. To distribute this irrigation water, sprinkler systems were needed. Most farmers opted for huge pivot irrigators. These irrigators have rotating arms hundreds of metres long, necessitating the near -total removal of thousands of long-established tree shelterbelts across the plains.

These shelterbelts had been grown over more than a century to stop the nor'west winds drying all the moisture out of the soil. With the shelterbelts gone, in strong nor'west conditions the moisture is sucked from the farmland faster than the irrigators can replace it.

The irrigation water was taken from rivers and groundwater. From 1999 to 2006 , water use increased by around $90 \%$, and Canterbury now uses around 35 times more than the national average (excluding Otago, which uses about half of Canterbury's amount).

As the world becomes more aware of the host of environmental issues facing civilisation, many people, particularly in premium markets, are looking critically at the environmental footprints of everything they consume. This awareness will eventually highlight the extraordinarily high water footprint of Canterbury dairy products.

Water footprints are used for many products as part of lifecycle analyses. They are calculated from the amount of water needed to produce each unit of a product. The water footprint is made up of three components: rain and irrigation waterknown as green and blue water respectively - and grey water, which is the amount of water needed to dilute any contamination from the production process to a healthy level in the receiving environment.

The water footprint for dairy production in Canterbury is eye-wateringly large: many tens of thousands of litres for every kilogram of milk solids. The biggest component of this water footprint is grey

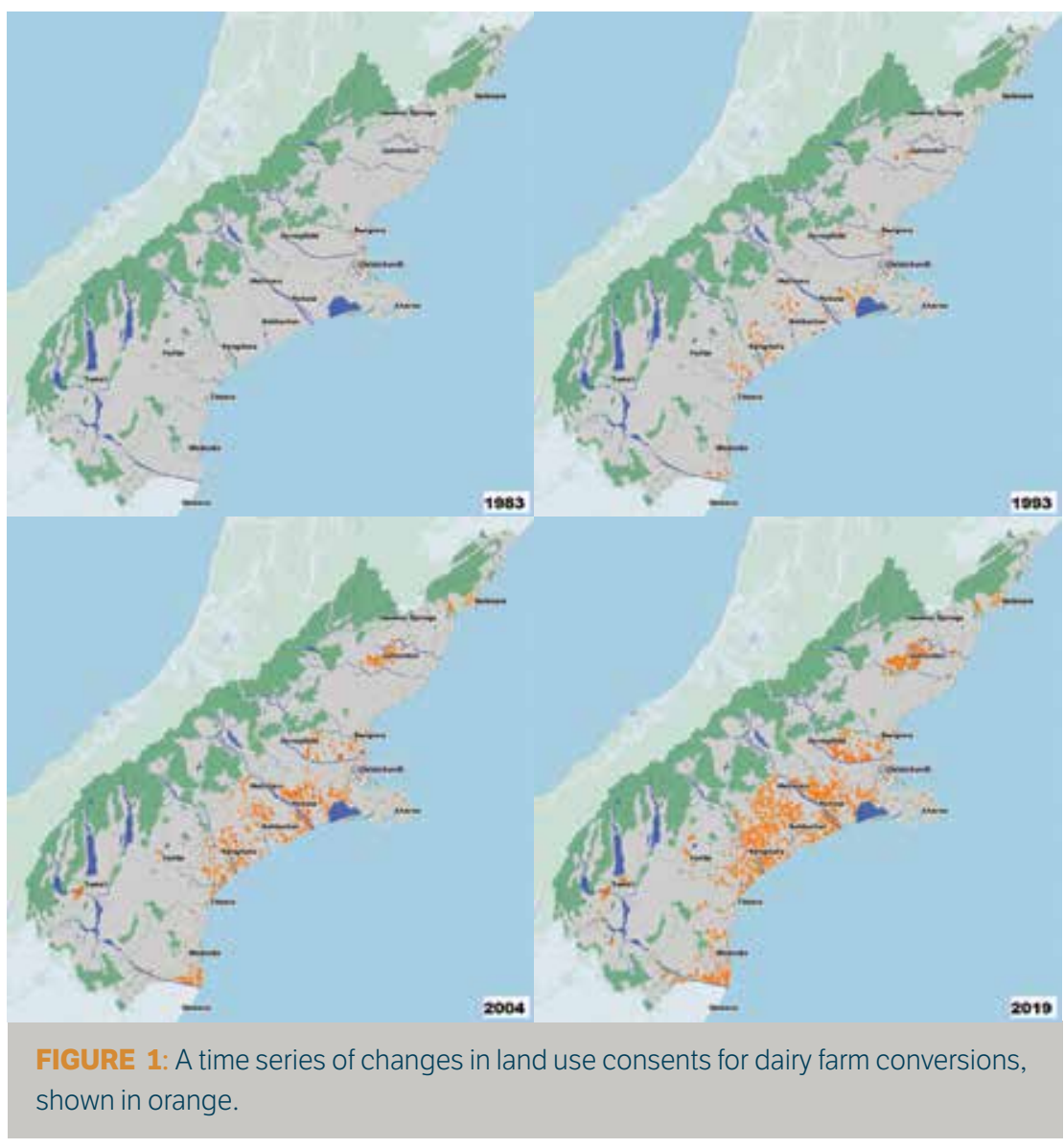

water, the water required to dilute leached nitrate to a healthy level for ecosystems and drinkers of the water. To give an indication of just how far Canterbury dairy farming has overshot sustainable levels, at least 25 times more rainfall would be needed to dilute the current nitrate losses, or conversely a 25 -fold reduction in farming intensity.

The reason nitrate is the big contamination issue in Canterbury is the animal stocking rates - that is, the intensity - occurring on stony, light and very permeable soils. This means there is a large amount of nitrate being leached, mostly from cow urine, and its movement is very rapid and almost unrestricted through soils and into aquifers and rivers. This extreme level of contamination is revealed in Canterbury District Council and NIWA monitoring of nitrate levels in aquifers and rivers, which have been rising inexorably since the dairy bonanza began.
Human health is the other reason nitrate contamination is the major freshwater issue for Canterbury, because the water supply for most Cantabrians is sourced from groundwater. Recent studies in Europe and the US have shown that our current maximum allowable value of nitrate is many times the level associated with colorectal cancer. Monitoring of drinking water from Canterbury shows many people are drinking water contaminated to levels exceeding those shown to be associated with cancer. New Zealand has very high rates of colorectal cancer, and the highest rates are found in Canterbury.

Until 1980, nitrogen for grass growth in New Zealand was obtained naturally, via the use of clover plants to fix atmospheric nitrogen. This placed a natural limit on stocking density. Then the third National Government constructed the Kapuni urea plant as one of its 'Think Big' projects. This 


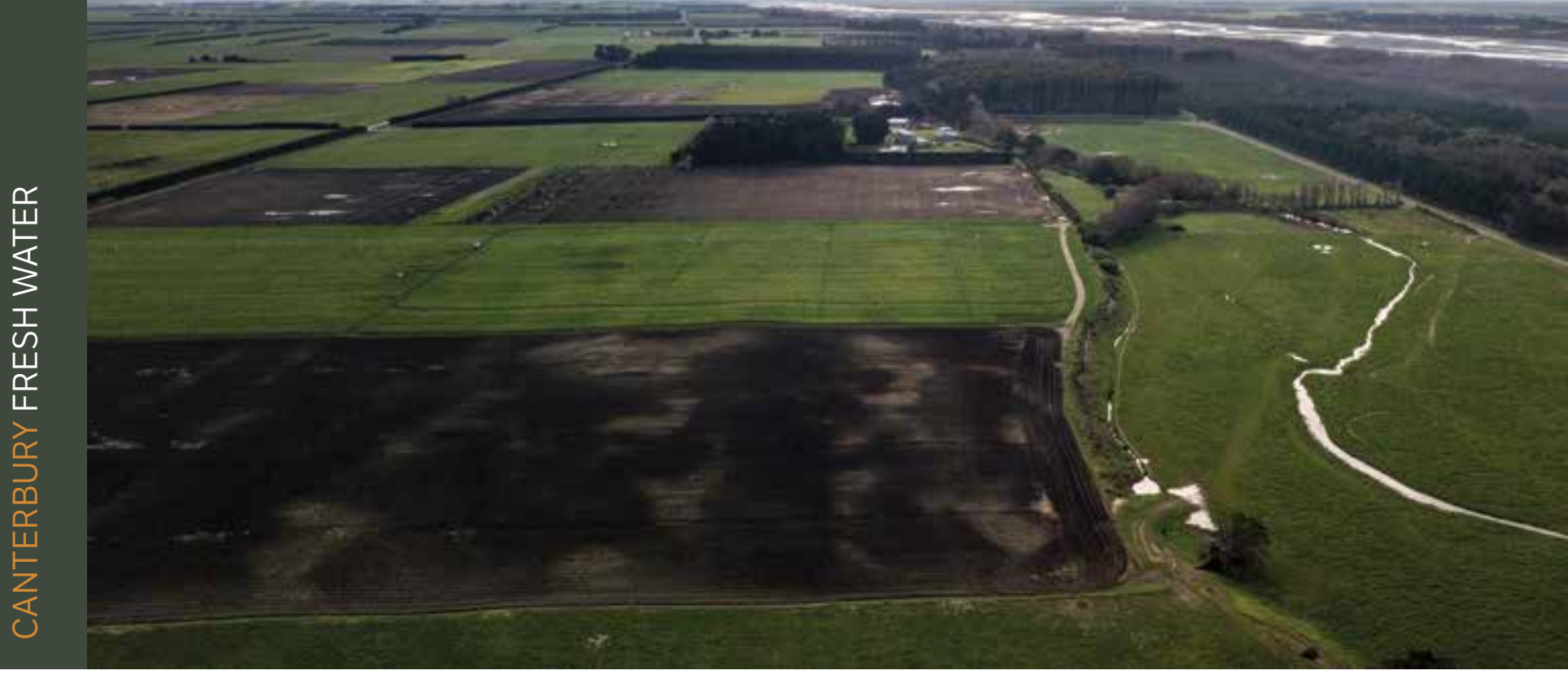

plant manufactured urea from Kapuni gas, and farmers were encouraged to take up its use. Between 1990 and 2015, nitrogen fertiliser use nationally increased by $627 \%$ (from 59,000 tonnes in 1990 to 429,000 tonnes in 2015).

Today only around one-third of the country's fossil-derived synthetic nitrate fertiliser supply comes from Taranaki, with the rest imported from the Middle East. The fertiliser is added to grow more grass at crucial times. The cows eat the grass and make milk, but only a small amount of the nitrogen consumed goes out in the milk, with the rest excreted in urine, to cause the multitude of problems described above.

Water taken for irrigation has major negative ecosystem implications beyond these. Any irrigation that does not evaporate makes its way back to aquifers and rivers, carrying extra nitrate. Furthermore, taking river water has major impacts on the ecology and geomorphology of the rivers and on the coastal environment. Rivers dammed for irrigation have altered flow variability that can have multiple impacts on ecosystems. The reduction in river flows concentrates nutrients and reduces the power of floods to move sediment and algae, and can reduce the opening of gravel estuarine bars to the ocean.

Fishers and recreational users of rivers in Canterbury have been vocal about the destruction of their recreational opportunities caused by the multiple impacts of agriculture on waterways. Many swimming areas have been closed due to faecal contamination.

The allocation of such huge amounts of water to intensify farming is unprecedented in New Zealand. It is effectively a transfer of wealth from public or Māori ownership to a few private landowners. While the official statement around ownership of water in New Zealand is that 'no-one owns water', irrigation water is traded for huge sums of money. The website for water trading hydrotrader (www.hydrotrader.co.nz) reveals the large sums of money associated with irrigation water trading.

The 'no-one owns water' mantra given by the New Zealand Government is in effect a cop-out: central governments have avoided the politically risky situation of dealing with ownership of water in relation to the Treaty of Waitangi. This avoidance leaves open the opportunity for entrepreneurs to take water at no cost and bottle and sell it to New Zealanders.

Because of publicity around nitratecontaminated drinking water in Canterbury, more people will turn to buying bottled water. Thus the failure to protect water means a boom in sales for bottling companies, which can source water for free from the deeper bores with - as yet - uncontaminated water.

The justification given by authorities for not limiting the expansion of dairy and associated irrigation in Canterbury is the claimed economic gains for the region. The rhetoric has been that the land use changes brought great wealth. 
Now, as the impacts become more obvious, it is clear that the gains were short-term and the costs horrendous.

Another example of the costs of the conversions comes from a report recently commissioned by Environment Canterbury (ECan) to estimate the cost of reducing the nutrient load getting into Te Waihora (Lake Ellesmere) in order to meet minimum legal requirements for lake health under the National Policy Statement for Freshwater Management.

The study estimated the cost of nutrient reduction either through reducing farming intensity in the catchment (the bulk of nutrients come from dairy) or by creating a wetland for nutrient reduction through the uptake of nutrients before they get into the lake. The resulting estimate was that to meet the minimum nutrient limit to restrict the decline of the lake the cost would be $\$ 380$ million for the wetland, and for the alternative, the farming intensity reduction, around $\$ 300$ million in lost revenue.

The conclusion of the report, and the response from ECan officials, was that the economic impact of mitigation in either case was so high that nothing would be done. By allowing the continued pollution ECan is in effect subsidising the dairy industry in the catchment of Te Waihora to the tune of $\$ 300-\$ 380$ million.

This indirect subsidy is not the only such example in New Zealand. A very similar situation at a larger scale can be seen at two North Island lakes. Lake Taupō and Lake Rotorua both have taxpayer and ratepayer funds being used to pay farmers not to dairy farm in the lake catchments, so as to limit nutrients entering the lakes. The money is paid to stop intensive farming, and the price being paid in the case of Lake Rotorua is $\$ 40$ million. Since the aim is to reduce nitrate flow into the lake by 100 tonnes, this is equivalent to $\$ 400$ per kilogram of nitrate leached from farms. A similar amount was paid in the Lake Taupō example.

An estimate of the total amount of nitrate-nitrogen leached from livestock in 2017 in Canterbury is more than 30 million kilograms. If the same rate were paid out as in the North Island examples, that would amount to $\$ 12$ billion per year. In other words, dairy farmers in Canterbury are subsidised to the tune of $\$ 12$ billion per year by not having to pay.

The contamination of fresh water in Canterbury would have to rank among the worst environmental disasters in New Zealand's history. In hindsight, it is clear where it all went wrong. ECan is tasked under the Local Government Act 2002 with protecting the environment, but it is also tasked with achieving economic growth. There will always be a tension between these two roles. It is hardly surprising that for the bureaucrats and elected officials in these organisations, economic growth in the short term is far more important than some future impact that they will likely not have to deal with.

While the Canterbury earthquakes left a terrible scar on the landscape and on Cantabrians, they were a natural event. The contamination of Canterbury's fresh water was and continues to be a dereliction of duty by the environmental protection agencies of New Zealand. There have clearly been failures at a national level with legislation, but the regional council must take the lion's share of the blame for failing to protect the environment, instead favouring private gains for the irrigation, dairy and fertiliser companies. In the process, it has put at risk the health of residents and destroyed many recreational opportunities, along with untold cultural impacts. We are only beginning to see the results of this failure to protect the most important things. (ㅇ)

\section{REFERENCES:}

Anonymous. Snapshot of water allocation in New Zealand. www.mfe.govt.nz/sites/default/files/ snapshot-water-allocation-nov06.pdf (accessed 25 July 2019). Prepared for Ministry for the Environment, Aqualinc Research Limited, 2006

Anonymous. Bowel cancer. www.health.govt.nz/ your-health/conditions-and-treatments/diseasesand-illnesses/bowel-cancer (accessed 25 July 2019). Ministry of Health, 2019

Anonymous. Nitrogen and phosphorus in fertilisers. www.stats.govt.nz/indicators/nitrogen-andphosphorus-in-fertilisers 18 April 2019 (accessed 25 July 2019). Stats NZ, 2019
Anonymous. New Zealand's Environmental Reporting Series: Environment Aotearoa 2019. Publication number: ME 1416 www.mfe.govt.nz/sites/default/files/ media/Environmental\%20reporting/environmentaotearoa-2019.pdf (accessed 25 July 2019). Ministry for the Environment and Stats NZ, 2019

Anonymous. Annual groundwater quality survey shows little change. ecan.govt.nz/get-involved/news-andevents/2019/groundwater-quality-survey-release (accessed 25 July 2019). Environment Canterbury Regional Council, 2019

Ausseil A-G, Manderson A. Spatial nitrate leaching extent: An update for environmental reporting. Prepared for the Ministry for the Environment, June 2018, Manaaki Whenua-Landcare Research, 2018

Ballingall J, Pambudi D. Dairy trade's economic contribution to New Zealand. NZIER report to DCANZ, February 2017

Bradshaw CJA, Giam X, Sodhi NS. Evaluating the relative environmental impact of countries. PLOS One, doi.org/10.1371/journal.pone.0010440, 2010

Dunn NR, Allibone RM, Closs GP, Crow SK, Bruno DO, Goodman JM, Griffiths M, Jack DC, Ling N, Waters JM, Rolfe JR. Conservation status of New Zealand freshwater fishes. Department of Conservation, New Zealand Threat Classification Series 24, www. doc.govt.nz/Documents/science-and-technical/ nztcs24entire.pdf, 2017

Harris S, Davie T. Selwyn Te Waihora zone memorandum on the implications of meeting the National Policy Statement for Freshwater Management objectives for lake environments in Te Waihora, June 2017. www.mfe.govt.nz/sites/default/files/media/ Fresh\%20water/18-D-02833.pdf (accessed 25 July 2019), 2017

Joy M, Baker M. Drinking water study raises health concerns for New Zealanders. The Conversation, theconversation.com/drinking-water-study-raiseshealth-concerns-for-new-zealanders-108510, 2019

Joy M, Foot EK. Damn the dams. The Journal of Urgent Writing, www.researchgate.net/profile/M_Joy/ publication/321094881_Damn_the_dams/ links/5a0e2739a6fdcc2b5b5df0a2/Damn-the-dams. pdf (accessed 25 July 2019), 2017

Joy M, McLean S. Despite its green image, New Zealand has world's highest proportion of species at risk. The Conversation, theconversation.com/despiteits-green-image-nz-has-worlds-highest-proportion-ofspecies-at-risk-116063, 2019

Joy MK, Foote KJ, McNie P, Piria M. Decline in New Zealand's freshwater fish fauna: Effect of land use. Marine and Freshwater Research 70(1), 114-24, doi. org/10.1071/MF18028, 2018

Schullehner J, Hansen B, Thygesen M, Pedersen CB, Sigsgaard T. Nitrate in drinking water and colorectal cancer risk: A nationwide population-based cohort study. International Journal of Cancer 143(1), 73-9, doi: 10.1002/ijc.31306, 2018

Todd K. Water bottling idea criticised as 'dangerous' economic thinking, Radio New Zealand National, www. rnz.co.nz/news/national/379844/water-bottling-ideacriticised-as-dangerous-economic-thinking 10 jan 2019 (accessed 25 July 2019), 2019 